\title{
UNIQUE SHORT-FACED MIOCENE SEAL DISCOVERED IN GRYTSIV (UKRAINE)
}

\author{
I. A. Koretsky, S. J. Rahmat* \\ Laboratory of Evolutionary Biology, Department of Anatomy, College of Medicine, \\ Howard University 520 W St. NW, Washington, DC 20059 (USA) \\ ${ }^{*}$ Corresponding author \\ E-mail: sulman.rahmat@howard.edu

\section{S. J. Rahmat (https://orcid.org/0000-0001-7410-8178)}

Unique Short-Faced Miocene Seal Discovered in Grytsiv (Ukraine). Koretsky, I. A., Rahmat, S. J. Numerous Miocene terrestrial mammal fossils have been discovered at the Grytsiv locality of Ukraine, but this is the first record of a fossil marine mammal at this site. Morphological analysis of the rostral portion of this middle-late Miocene (12.3-11.8 Ma) partial skull suggests that it belongs to the subfamily Phocinae. The small size and cranial morphology of this partial skull is compared with recent and fossil representatives of the extant subfamily Phocinae and the extinct subfamily Devinophocinae. Extinct and modern representatives of the extant subfamilies Cystophorinae and Monachinae were not incorporated in this study due to their extremely large size in comparison to this new find. This newly described skull belonged to a small-sized seal (likely similar in size to the modern sea otter based on the width of the rostrum) with an extremely short rostrum and several other diagnostic characters that differ from all other fossil and extant phocines. Due to the lack of preservation and fragility of fossil seal skulls, less than 20 have been described so far. This new skull is yet another example of an ancestral seal, supporting the suggestion that modern seals have become larger over their evolutionary history. Overall, any cranial information on fossil true seals is extremely important since it allows resolving contentious phylogenetic relationships between extinct and extant representatives of this group.

Key words: Phocidae, Phocinae, Paratethys, Northern Black Sea region.

\section{Introduction}

A rich assemblage of fossil mammals of Miocene age was discovered in the Grytsiv locality of Ukraine, including terrestrial small mammals such as rodents and pikas (Topachevsky and Skorik, 1992; Topachevsky et al., 1996; Topachevsky et al., 1998; Nesin and Nadachovski, 2001; Nesin and Kovalchuk, 2020), insectivores (Topachevsky et al., 1996; Nesin and Kowalski, 1997; Rzebik-Kowalska and Topachevsky, 1997; Rosina and Semenov, 2012), as well as numerous large carnivorans such as mustelids, ursids, viverrids, felines, machairodonts and even amphicyonids (Wolsan and Semenov, 1996; Semenov, 2001; Morlo and Semenov, 2004). More recently, an impressive collection of fossil seal fauna in the Central Parathetyan region has been well documented and described, dating from the Sarmatian of the late Miocene (Koretsky and Ray, 1994; Koretsky, 2001; Koretsky and Holec, 2002; Koretsky, 2003; Koretsky and Rahmat, 2013; Rahmat and Koretsky, 2016; 2018). The discovery of the partial rostral portion of a seal skull is the first marine mammal fossil ever found in Grytsiv locality. Morphological analysis of the rostral portion of this middle-late Miocene partial skull suggests that it belongs to the subfamily Phocinae, allowing for a more accurate diagnosis of the subfamily and helping to resolve contentious phylogenetic relationships within the family Phocidae. Cranial morphology of this partial skull is compared to those of recent and fossil representatives of the extant subfamily Phocinae and the extinct subfamily Devinophocinae. Fossil and modern representatives of the extant subfamilies Cystophorinae and Monachinae were not incorporated in this study due to their extremely large size in comparison to this new finding. 
Grytsiv [Hrytsiv, or Grytsiv] (fig. 1): Shepetivskyi District of Khmernytskyi Region; deposits are in the limestone quarry (a reef zone) on the right bank of Khomora River; $3 \mathrm{~km}$ W from Hrytsiv village; latitude $49^{\circ} 58^{\prime}$ $\mathrm{N}$, longitude $27^{\circ} 12^{\prime} \mathrm{E}$. Karstic sinkholes, filled with bone-bearing sediments, were found in this limestone bed (thickness up to $10 \mathrm{~m}$ ). The overlying deposits were represented by calcareous gravelstones and clays and contained fossil mollusks (Topachevsky et al., 1996). The Grytsiv locality has a rich and taxonomically diverse fossil assemblage, with a broad taxonomic diversity, and corresponds to zone MN 9 (Bessarabian regional stage of the Middle Sarmatian in the regional scheme), Middle-Late Miocene (Korotkevich, 1988; Vangengeim et al., 2006). Carnivoran terrestrial fauna found in Ukraine dates to the early Vallesian (late Miocene) and belongs in MN 9, similar to other European faunas. The Middle Sarmatian (12.3-11.2 Ma) corresponds to the marine Tortonian Stage (Mediterranean or Khersonian Stage of the Eastern Paratethys; according to The Geological Time Scale; Gradstein, 2012). Newer studies specify the age of the Grytsiv fossiliferous strata as being 11.146$11.056 \mathrm{Ma}$ (Vasilyan et al., 2013; Kirscher et al., 2016). The rostral part of this seal skull was discovered in brown mud, the main filler of karst deposits (fig. 1, \# 8).

All fossil material described was collected during 1983-1995 and is stored in the Department of Paleontology of the National Museum of Natural History (NMNHU-P), National Academy of Sciences of Ukraine in Kyiv.

\section{SYSTEMATIC PALEONTOLOGY \\ Class MAMMALIA Linnaeus, 1758 \\ Order CARNIVORA Bowdich, 1821 \\ Family PHOCIDAE Gray, 1825 \\ Subfamily PHOCINAE Gray, 1821}

Emended Diagnosis. The newly described skull fits the diagnosis for subfamily Phocinae given by Koretsky (2001:34) by the upper dental formula: I3, C1, P4, M1. Incisors form a straight line, P2-M1 double-rooted (in contrast to seals of the subfamily Cystophorinae) with posterior root larger than anterior one; roots not fused, except M1. M1 much smaller than P4, triangular with two small cusps; anterior palatal foramina deep, round; palatal groove weakly pronounced.
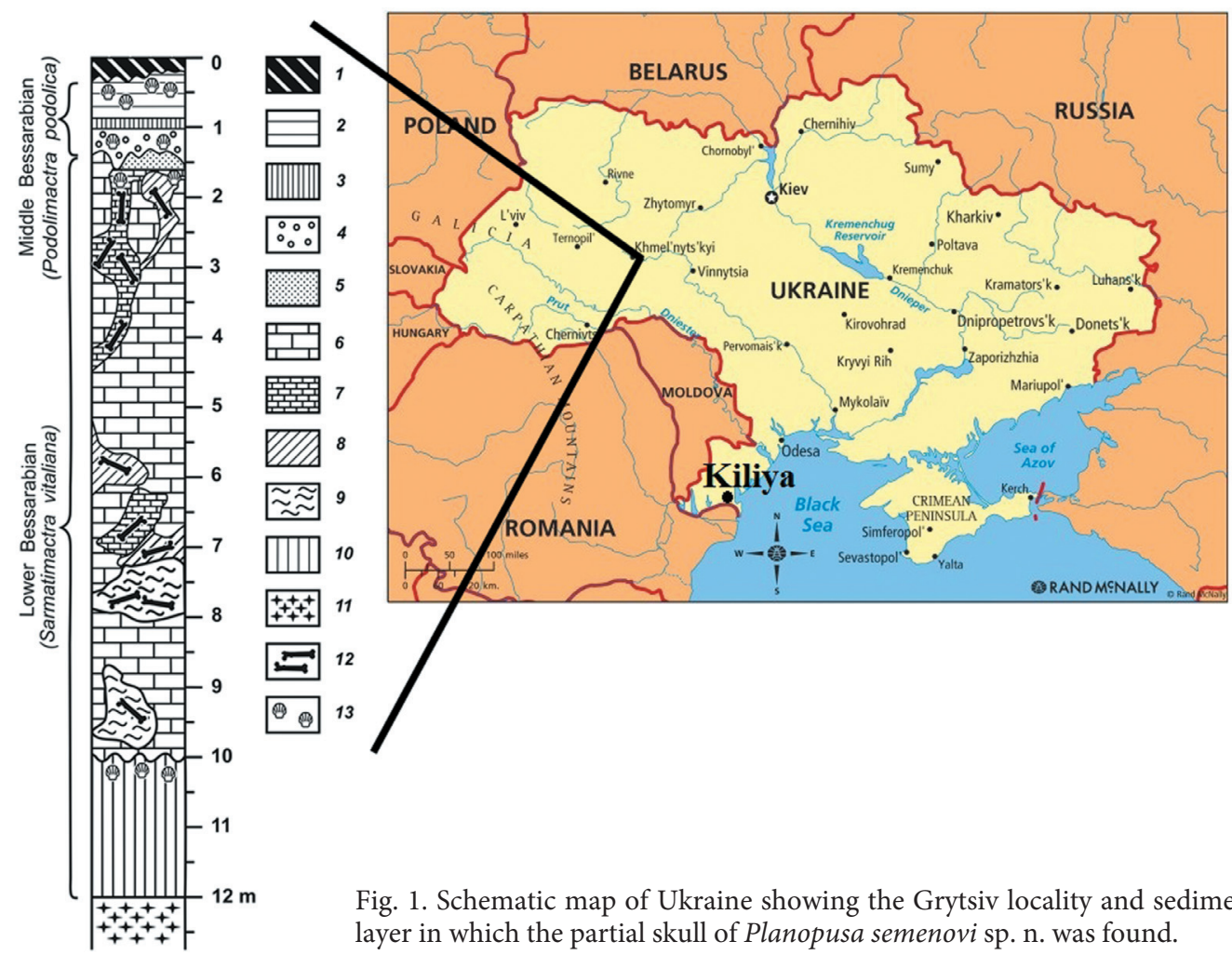

Fig. 1. Schematic map of Ukraine showing the Grytsiv locality and sediment layer in which the partial skull of Planopusa semenovi sp. n. was found. 
Tribe Phocini Chapskii, 1955

Definition. All taxa that are closely related to genera Phoca, Histriophoca, and Pusa. The apomorphic characters defining the tribe Phocini include: the length of zygoma (without processes) is more than in 1.5 times larger than the minimal width of interorbital width; a tympanic bulla is triangular and lacks the process covering internal carotid foramen; upper incisors flattened laterally, and the depth of the alveolus is more than half of total tooth length; paraoccipital process poorly developed or absent.

\section{Subtribe Phocina Chapskii, 1955}

Definition (after Chapskii, 1955). All taxa that are closely related to Pusa hispida, Pusa capsica, Pusa sibirica, Halichoerus grypus and Monachopsis pontica, the smallest recent and fossil seals. The apomorphic characters defining the subtribe Phocina are: inframeatal lip of the external auditory meatus is poorly developed; proximal edge of the palatal process of the maxilla has a deep angular or oval shape; inferior temporal process of zygoma is much longer than superior; a nasal septum is shorter than the hard palatine; proximal and distal width between tympanic bullae almost equal.

\section{Plantopusa, gen. n.}

Diagnosis. As for the type species.

Etymology. From Latin - Plana = flat; from Greek micro - short, small; "semenovi" in honour of Dr. Yuriy Semenov (Palaeontological Museum of the National Museum of Natural History, National Academy of Sciences of Ukraine, Kyiv = NMNHU-P) in recognition of his contributions to the discovery and collecting of this fossil material.

Type and only known species. Planopusa semenovi, new species.

Planopusa semenovi, sp. n. (figs 2-5; tables 1-3)

Holotype. NMNHU-P 64-709, rostral part of the skull with I3, C, P1, P2, and isolated P4 and M1; P3 is absent (fig. 2). Collected by Yu. A. Semenov in 1995 and stored in the NMNHPM.

Type locality. Grytsiv, Shepetivskyi District Khmelnytskyi Region, Western Ukraine, karst deposits in limestone quarry on the right bank of Chomora River, $3 \mathrm{~km}$ west of village of Grytsiv; $49^{\circ} 58^{\prime} 05.2^{\prime \prime} \mathrm{N} 27^{\circ} 10^{\prime} 03^{\prime \prime} \mathrm{E}$ (reef zone).

Formation and Age. Middle Sarmatian, middle-late Miocene; MN 9, likely in the interval from 11.146-11.056 Ma.

Diagnosis. Small seal with extremely short rostrum (table 1), differing from all other fossil and extant phocines by: 1) flattened palatal process of maxilla; 2) P4 longer than M1; 3) alveoli form a straight line; 4) wider rostrum across canines compared to other small Phocinae (but narrower than in Monachopsis pontica).

Description. The partial skull likely belongs to an adult, based on the fused sutures. However, teeth are not worn, characteristic for sub-adults. The maxilla has a very short convexity over P1 and convexity started over P2. The incisive bone is partially broken and palatal process of the maxilla is flattened from the level of the anterior alveolus of P2. The large grooves (fissura palatine) from anterior palatal foramina are directed towards the incisors (as in Enhydra lutris, fig. 3), in contrast to the condition stated by Wozencraft (1989) for other phocids, but similar to seals of the subfamily Devinophocinae (Koretsky and Holec, 2002; Koretsky and Rahmat, 2015). The concave palatine is wider $(18.0 \mathrm{~mm})$ between canines, similar to that in Devinophoca emryi (Koretsky and Rahmat, 2015).

The hard palate is half the length of the smallsub-adult of Pusa caspica. Palatal grooves are shallow, but present without the posterior palatal foramen. Part of the palatal bone is missing. Posterior border of the anterior palatal foramen is situated at the level of P1 (in contrast to that in Pusa caspica where it is between C and P1). In coronal view, the space 


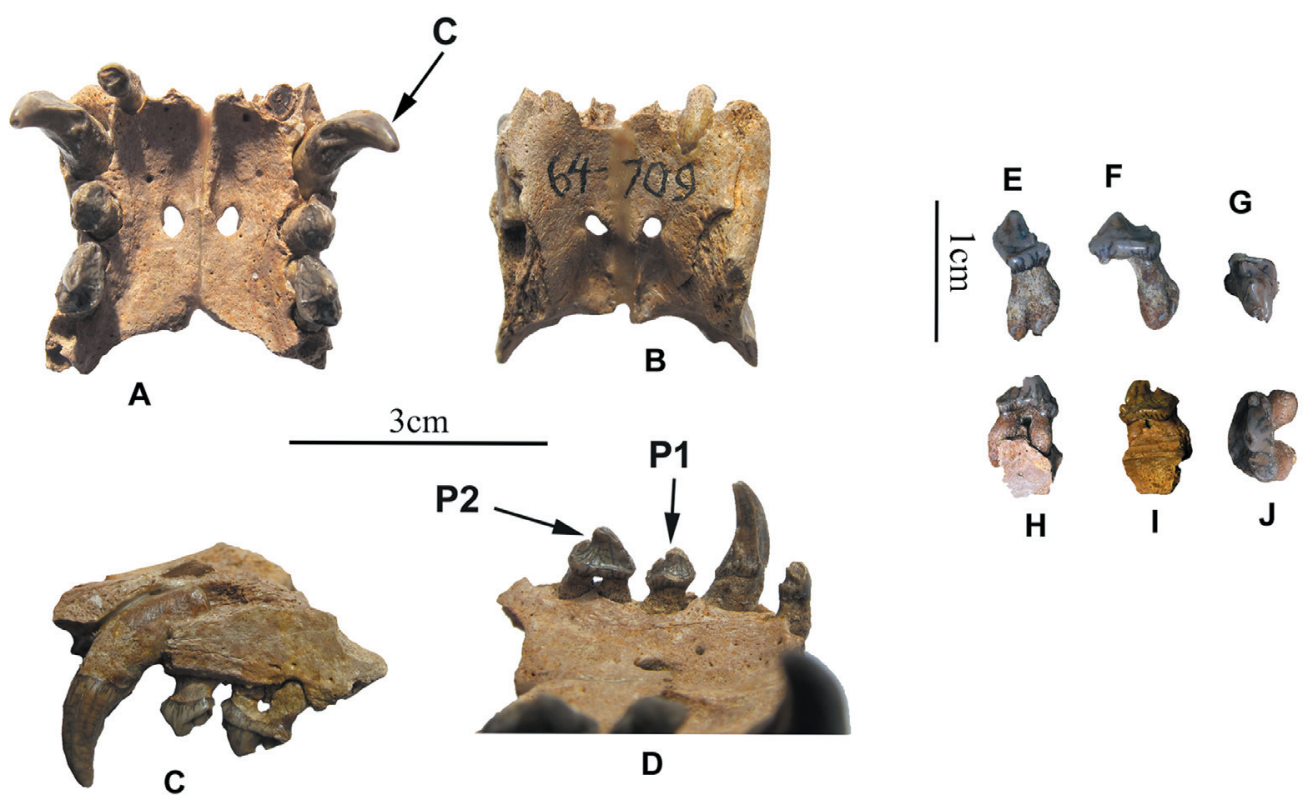

Fig. 2. Rostral portion of the partial skull of Planopusa semenovi sp. n. (NMNHU-P 64-709) in ventral (A), dorsal (B), lateral (C) and medial view (D). Upper P4 tooth in labial (E), lingual (F) and occlusal view (G). Upper M1 tooth in labial (H), lingual (I) and occlusal view (J). C - upper canine, P1 - upper first premolar; P2 - upper second premolar.

between the posterior border of the anterior palatal foramen and the anterior border for the choanae is $7.5 \mathrm{~mm}$ ( $11.0 \mathrm{~mm}$ in Pusa caspica).

The lingual alveolar margins of canines and incisors are at the same level as those of the cheek teeth (as in D. emryi), but alveolar margins of $\mathrm{C}$ and $\mathrm{P} 1$ are compressed towards the midline. From the anterior palatal foramina to the level of P2, the palatine is flat. A deep, antero-posteriorly aligned groove (sulcus palatinus) is present posterior to $\mathrm{P} 2$, characterized as a derived condition among phocids according to Wyss and Flynn (1993) and in contrast to D. emryi.

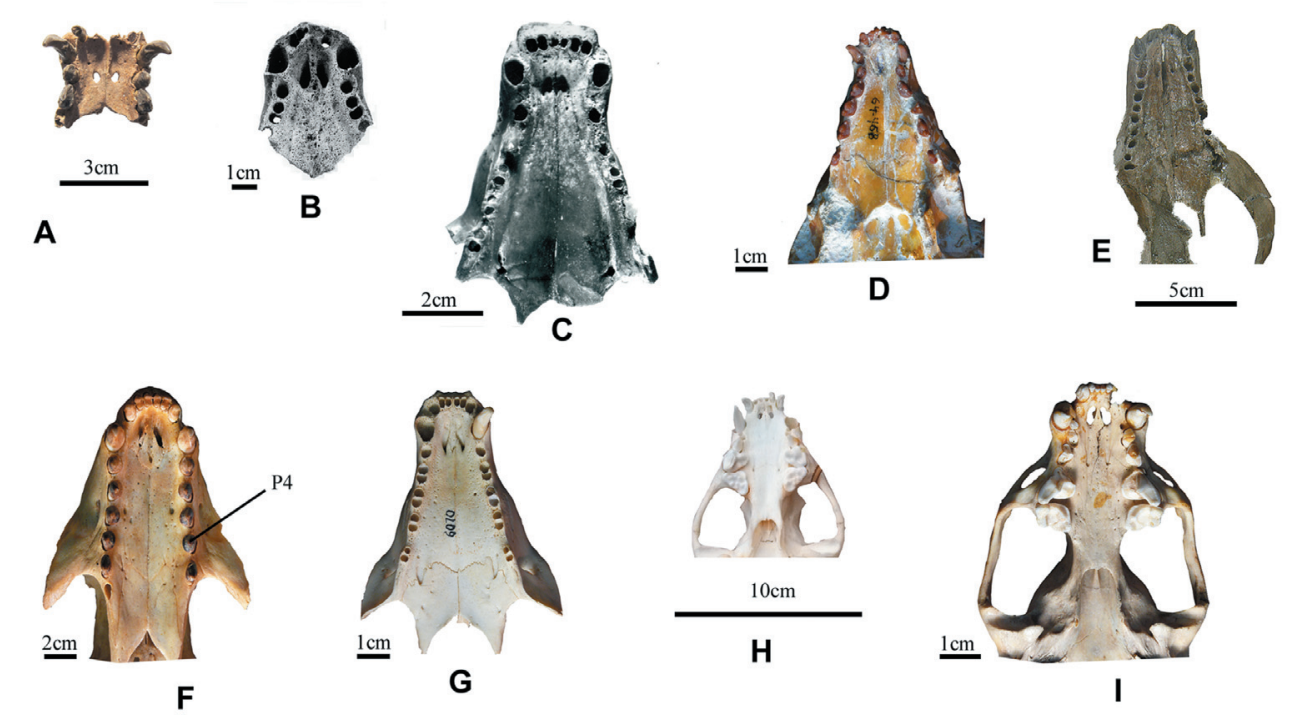

Fig. 3. Skull ventral views: A - Planopusa semenovi sp. n. (NMNHU-P 64-709); B - Leptophoca lenis (CMMV-2021); C - Histriophoca alekseevi (IZUAN 40-121); D - Praepusa tarchankutica (NMNH- 64-469); E - Leptophoca lenis (CMM- V-2021); F - Callorhinus ursinus; G - Pusa caspica; H - Taxidea taxus, and I - Lutra lutra. 
Table 1. Cranial measurements, mm

\begin{tabular}{|c|c|c|c|c|c|c|c|c|}
\hline \multirow[b]{2}{*}{ Characters } & \multirow[b]{2}{*}{ 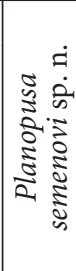 } & \multirow[b]{2}{*}{ 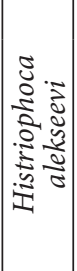 } & \multirow[b]{2}{*}{ 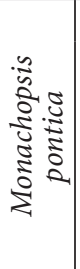 } & \multirow{2}{*}{ 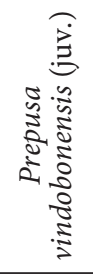 } & \multirow[b]{2}{*}{ 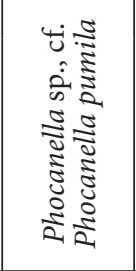 } & \multirow[b]{2}{*}{ 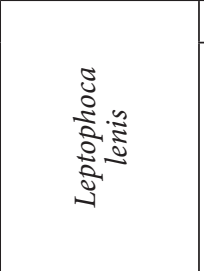 } & \multicolumn{2}{|c|}{ Devinophoca } \\
\hline & & & & & & & claytoni & emryi \\
\hline 1. Total length & & & & 116.0 & & 220.0 & 119.9 & 119.5 \\
\hline 2. Condylobasal length & & & & 127.0 & & 208.0 & 119.3 & 118.0 \\
\hline 3. Length of palatine process & & 55.5 & & 65.0 & & 83.0 & 71.0 & 81.0 \\
\hline $\begin{array}{l}\text { 4. Length of rostral part, measured } \\
\text { from antero-upper corner of orbit }\end{array}$ & & 52.0 & & 47.0 & & $63.7-69$ & 49.0 & 60.0 \\
\hline $\begin{array}{l}\text { 5. Length of braincase, measured } \\
\text { from posterior corner of orbit }\end{array}$ & & & & 83.0 & & 84.0 & 93.5 & 70.0 \\
\hline 6. Length of tympanic bulla & & & & 23.0 & & $29.0-35.0$ & 38.5 & 33.6 \\
\hline 7. Length of toothrow, P1-M1 & & 35.0 & 29.0 & 34.0 & & 60.0 & $49.0-53.2$ & 46.9 \\
\hline 8. Length of toothrow, P2-P4 & & 20.5 & & 20.5 & & $38.0-40.0$ & $32.5-34.5$ & 28.9 \\
\hline $\begin{array}{l}\text { 9. Maximum diameter of } \\
\text { infraorbital foramen }\end{array}$ & & & & & & $9.0-11.0$ & $7.5-11.2$ & $11.2-12.1$ \\
\hline 10. Length of temporal fossa & & & & 38.5 & & $63.6-68.0$ & 61.5 & 61.5 \\
\hline $\begin{array}{l}\text { 11. Width of rostrum across } \\
\text { canines }\end{array}$ & 30.5 & 24.5 & & 19.5 & $40.0-40.5$ & $33.0-36.0 ; 47.0$ & 40.0 & 47.7 \\
\hline 12. Maximal infraorbital width & & & & & & $16.0-22.0$ & 25.5 & 22.0 \\
\hline 13. Minimal infraorbital width & & & & 5.5 & & $12.7-15.0$ & 14.0 & 19.4 \\
\hline $\begin{array}{l}\text { 14. Width of skull across of } \\
\text { zygomatic process of squamosal }\end{array}$ & & & & 66.0 & & $112.0-116.0$ & 124.0 & 127.7 \\
\hline 15. Width of braincase & & & & 65.0 & & $85.0-114.0$ & 88.0 & 78.3 \\
\hline 16. Mastoid width & & & & 68.5 & & $92.0-140.0$ & 113.0 & 102.3 \\
\hline $\begin{array}{l}\text { 17. Width of palatine process } \\
\text { between P1's }\end{array}$ & 15.5 & 13.5 & 17.0 & 9.0 & $20.0-21.0$ & $15.5-19.0 ; 24.0$ & 10.5 & 20.8 \\
\hline $\begin{array}{l}\text { 18. Maximum width of palatine } \\
\text { process }\end{array}$ & 23.5 & 44.0 & 38.0 & 35.0 & $34.5-35.0$ & $45.3-50.5$ & 55.5 & 40.9 \\
\hline $\begin{array}{l}\text { 19. Maximum width of infraorbital } \\
\text { foramen }\end{array}$ & & 10.0 & 7.9 & 7.0 & & $7.0-9.0$ & $9.0-10.0$ & 7.2 \\
\hline 20. Width of tympanic bulla & & & & 22.5 & & $28.3-35.0$ & 49.3 & 35.7 \\
\hline 21. Width of rostrum & 30.5 & 18.0 & 30.0 & 15.0 & 33.00 & $25.0-30.0 ; 40.0$ & 37.0 & 45.8 \\
\hline $\begin{array}{l}\text { 22. Height of skull in region of } \\
\text { tympanic bulla }\end{array}$ & & & & 52.0 & & $69.0-71.0$ & 80.0 & 81.7 \\
\hline $\begin{array}{l}\text { 23. Distance from center of } \\
\text { stylomastoid foramen to center of } \\
\text { postglenoid foramen }\end{array}$ & & & & 14.5 & & $19.5-20.0$ & 15.1 & 19.2 \\
\hline
\end{tabular}

Maxillary teeth: All teeth are very small with double roots (except C, P1). The incisors are arranged in a straight line. The roots of alveoli I3 are larger than I2, which in turn is larger than I1. The I3 crown is preserved with a small cingulum on the lingual side, round in cross-section. Cingula present only on lingual sides of the crown and do not extend the buccal (labial) side (in contrast to Devinophoca) (fig. 2).

Canines project ventrally, slightly worn (possibly sub-adult), but the anterior surface in both canines is worn or due to overbite with grinding of the lower canine (figs 2, 3). The diastema is absent between $\mathrm{C}$ and $\mathrm{P} 1$, which is located obliquely to the tooth row. The snout is shortened, but the canines are relatively large compared to the length of the snout and other teeth, supporting the overbite hypothesis where the lower canine wears the upper, similar to those in Gulo gulo (wolverine) (IZUAN 896, from the Archangelsk area). 
Diastemata between postcanine teeth are absent. All alveoli are rounded and the posterior roots of $\mathrm{P} 2, \mathrm{P} 4$, and $\mathrm{M} 1$ are larger than anterior roots. Tooth crowns are not worn. The large paraconid (central cusp) is turned caudally, with one small anterior cusp and a posterior cusp that is larger and positioned higher. The third cusp is placed on the basal cingulum, located caudally to the posterior cusp, and it is much smaller than other cusps (especially smaller on M1).

The P1 has a single root, oval in cross-section, almost intact (similar to Praepusa). Its crown is $5.0 \mathrm{~mm}$ long (table 2), with a conical (triangular) central cusp and cuspidate lingual cingulum bearing diminutive two posterior cusps (in contrast to D. emryi). Cinguli on P2, P4, and M1 are parallel to the lower enamel margin. On P2, P4, and M1, the gum line is parallel to the margin of the dentary. The complete crowns on postcanine teeth (except $\mathrm{P} 1$ ) are irregularly shaped in occlusal view (in contrast to $D$. emryi). The P1 is flattened disto-lingually on its lingual side. The cingulum, bearing minute cuspules, encircles the crown on the lingual side of the P1.

Table 2. Measurements of the upper dentition of Planopusa semenovi and other phocines, mm

\begin{tabular}{|c|c|c|c|c|c|c|c|c|c|c|}
\hline \multirow{3}{*}{ Teeth } & \multirow{2}{*}{\multicolumn{2}{|c|}{$\begin{array}{c}\text { Planopusa } \\
\text { semenovi sp. } \mathrm{n} .\end{array}$}} & \multirow{2}{*}{\multicolumn{2}{|c|}{$\begin{array}{c}\text { Monachopsis } \\
\text { pontica }\end{array}$}} & \multirow{2}{*}{\multicolumn{2}{|c|}{$\begin{array}{l}\text { Phocanella sp., cf. } \\
\text { Phocanella pumila }\end{array}$}} & \multicolumn{4}{|c|}{ Devinophoca } \\
\hline & & & & & & & \multicolumn{2}{|c|}{ claytoni } & \multicolumn{2}{|c|}{ emryi } \\
\hline & length & width & length & width & length & width & length & width & length & width \\
\hline I1 & & 2.5 & & & $4.0-4.0$ & $2.5-3.0$ & & 3.0 & & 3.6 \\
\hline $\mathrm{I} 2$ & & 3.5 & & & $5.0-5.5$ & $4.0-4.0$ & & 3.0 & & 3.7 \\
\hline I3 & 5.0 & 3.5 & & & $7.0-7.5$ & $5.0-5.6$ & & 5.7 & & \\
\hline $\mathrm{C}$ & 6.5 & 5.0 & & & & & 13.2 & 10.5 & 11.8 & 11.5 \\
\hline $\mathrm{P} 1$ & 5.0 & 3.8 & 4.0 & 5.0 & $6.5-7.5$ & $6.0-7.0$ & 6.5 & 5.6 & 6.2 & 5.2 \\
\hline $\mathrm{P} 2$ & 7.5 & 4.0 & 8.5 & 5.0 & $9.0-11.0$ & $7.0-7.0$ & 10 & 6.5 & 5.2 & 7.2 \\
\hline P3 & & & 8.0 & 4.0 & & & 10.0 & 8.0 & 9.6 & 7.0 \\
\hline $\mathrm{P} 4$ & 7.0 & 4.0 & 4.0 & 4.0 & & & 10.6 & 8.2 & $11.0-11.1$ & $5.7-7.1$ \\
\hline M1 & 5.5 & 3.5 & 3.0 & 3.0 & & & 9.3 & 7.5 & 8.0 & 4.7 \\
\hline
\end{tabular}
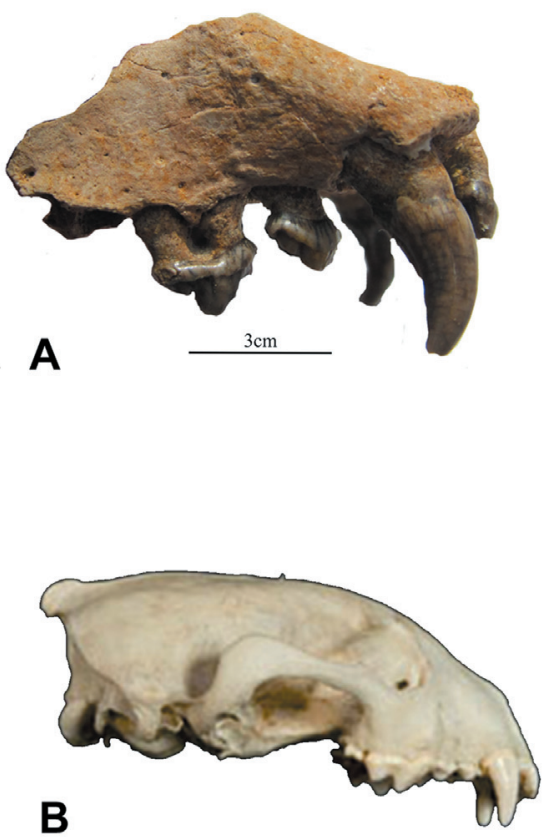
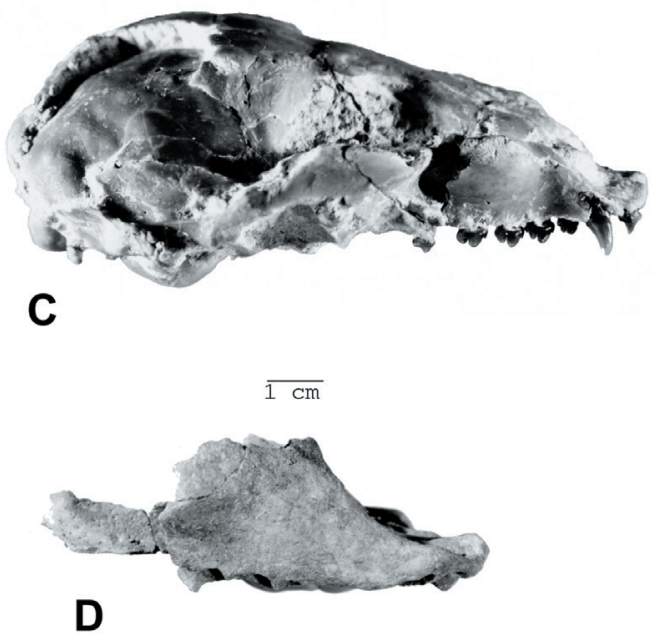

Fig. 4. Skull lateral views: A - Planopusa semenovi (NMNHU-P 64-709); B - Gulo gulo (IZYAN 896); C Praepusa vindobonensis (IZUAN N64-468, juvenile), and D - Leptophoca lenis (CMM- V-2021). 
The P2-M1 crowns are triangular in occlusal view and slightly worn. The P2-M1 teeth have two roots, both round in cross-section. The posterior root on P2 is wider and much larger than the anterior alveolus. The P2 is situated in parallel to the tooth row. The P2 crown has a very prominent lingual cingulum with a minute anterior cingular cusp and slightly larger than two posterior cusps. The cingulum on the labial side extends around the entire tooth (in contrast to D. emryi) with carinae (sharp tooth edges) similar to those observed in Monachinae (Amson and Muizon, 2014).

The buccal side of the $\mathrm{P} 4$ is straight. This tooth has the widest crown base. Posterior root is larger than anterior one, with one anterior cusp, two posterior cusps, and an additional cusp on the lingual side of the cingulum. The crown is triangular in occlusal view. The P4 is larger than M1.

The M1 is very small ( $5.5 \mathrm{~mm}$ long and $3.5 \mathrm{~mm}$ wide) with two fused roots. The crown is triangular in occlusal view, similar to other postcanines, but much smaller. The anterior cusp is absent, but there is a single posterior cusp and a gracile cingular posterior cusp. Cingulum on the labial side is absent; the tip of the tooth is turned caudally. Cingula are located transversely only on the lingual sides of the crown, not extending the labial (buccal) side (in contrast to those in Devinophoca).

\section{Comparisons with small-sized representatives of the family Phocidae}

\section{Subfamily PHOCINAE}

Due to the lack of preservation and fragility of fossil seal skulls, less than 20 specimens have been described so far, with only a few belonging to representatives of the subfamily Phocinae. This new partial seal skull of Planopusa semenovi is extremely small and has a short face (based on the size of the rostral part and teeth). Based on teeth formula, Pl. semenovi sp. n. belongs to the subfamily Phocinae and will be compared to other recent and fossil phocine seals.

\section{Planopusa semenovi differs from:}

Recent Pusa capsica by: being smaller, having well-developed, round anterior palatal foramen; the presence of palatal groove; the absence of diastema; the shape of the proximal edge of hard palate.

Phocanella sp., cf. P. pumila (Pliocene, Yorktown Formation 5.3-3.6 Ma) from Lee Creek Mine, USA (Ray et al., 2008) by: the lack of diastema between teeth; short concavity over P1 in preorbital part of the maxilla; the flattened palatal process of maxilla; the reverse ratios between $\mathrm{P} 4$ and $\mathrm{M} 1$; wider rostrum; rounded anterior palatal foramen, and deeper palatal groove.

Histriophoca alekseevi (Middle Miocene, middle Sarmatian [ 11.6-9.9 Ma] of the Eastern Paratethys) by: the absence of diastemata; the flattened palatal process of the maxilla; the reverse ratios between $\mathrm{P} 4$ and M1; wider rostrum; round and deep anterior palatal foramen; uneven depth of the palatal groove.

Monachopsis pontica (Middle Miocene, middle Sarmatian [ 11.6-9.9 Ma ] of the Eastern Paratethys) by: the smaller width of the palatal process; narrowest infraorbital foramen of any known fossil or modern seal, but larger than in other seals from the same region (such as Histriophoca alekseevi, and Praepusa vindobonensis); longer and narrower teeth; width of the rostrum part of the skull (table 1; which is similar in size to Leptophoca lenis despite the smaller size, but wider than in Histriophoca alekseevi).

Prepusa vindobonensis (middle Miocene, early Sarmatian [ 12.8-11.6 Ma] of the Central and Eastern Paratethys) by: upper incisors forming a straight line; the absence of diastemata; the short concavity over P1 in preorbital part of the maxilla; rounded anterior palatal foramen; the similar width of rostrum (despite overall smaller size). 
Leptophoca lenis (Early Miocene [ 16 Ma], USA) by: upper incisors forming a straight line; the absence of diastema; short concavity over P1 of the preorbital part of the maxilla; rounded anterior palatal foramen; similar width of the rostrum (despite overall smaller size).

\section{Subfamily DEVINOPHOCINAE}

Only the fossil sister taxa Devinophoca emryi and D. claytoni (early Mid-Miocene, Badenian, 16.3-12.8 Ma) are described within this subfamily. Planopusa semenovi differs from these taxa by: alveoli of upper incisors forming a straight line; pre-orbital part of the maxilla has very short concavity over P1 and convexity starting over P2; much smaller total size.

There are no described fossil cystophorine seal skulls to date. Described fossil monachine skulls have a different dental formula and are much younger in geological age; in addition, their skulls were much larger with a reverse ratio between M1 and P4.

\section{Cladistic analysis}

The data matrix for the 14 included characters is shown in table 3. Cranial, mandibular and dental characters and character-states for Phocidae: 0 , designates the most primitive state among the studied taxa; 1-2, derived states; ?, unknown or missing data. Some characters have the opposite polarity to that of Berta and Wyss (1994) and Burns and Fay (1970), while other characters have the same polarity as that of Chapskii (1974). Some characters were updated and modified from Koretsky (2001), Koretsky and Grigorescu (2002), and Koretsky and Rahmat (2015).

The analysis was performed with NONA after Goloboff (1999) and Winclada from Nixon (1999) using a heuristic search of the phocid taxa of 14 unweighted characters. The

Table 3. Matrix for cranial character-state data for Phocidae taxa $(\dagger=$ extinct)

\begin{tabular}{|c|c|c|c|c|c|c|c|c|c|c|c|c|c|c|}
\hline Species & 1 & 2 & 3 & 4 & 5 & 6 & 7 & 8 & 9 & 10 & 11 & 12 & 13 & 14 \\
\hline Allodesmus kelloggi $\dagger$ & 2 & 1 & 0 & 1 & 0 & 0 & 2 & 1 & 0 & 0 & 1 & 0 & 1 & 0 \\
\hline Lontra canadensis & 0 & 1 & 0 & 0 & 0 & 1 & 0 & 0 & 1 & 0 & 0 & 0 & 0 & 0 \\
\hline Puijila darwini $\dagger$ & 1 & 1 & 1 & 1 & 0 & 1 & 1 & 0 & 0 & 1 & 0 & 0 & 0 & 0 \\
\hline Devinophoca claytoni $\dagger$ & 1 & 0 & 0 & 0 & ? & 1 & 0 & 0 & 1 & 0 & 0 & 0 & 0 & 0 \\
\hline Devinophoca emryi $\dagger$ & 0 & 0 & 0 & 1 & 3 & 1 & 0 & 0 & 1 & 0 & 0 & 0 & 0 & 0 \\
\hline Cystophora cristata & 1 & 1 & 0 & 0 & 2 & 0 & 1 & 1 & 0 & 1 & 1 & 0 & 1 & 1 \\
\hline Mirounga leonina & 0 & 1 & 0 & 0 & 2 & 0 & 1 & 1 & 0 & 1 & 1 & 0 & 1 & 1 \\
\hline Monachus monachus & 2 & 0 & 1 & 0 & 1 & 1 & 1 & 0 & 1 & 0 & 0 & 1 & 0 & 0 \\
\hline Neumonachus schauinslandi & 2 & 0 & 1 & 0 & 1 & 1 & 1 & 0 & 0 & 0 & 0 & 1 & 1 & 0 \\
\hline Callophoca obscura $\dagger$ & 2 & 0 & 0 & 1 & 1 & 1 & 1 & 0 & 0 & 0 & 0 & 1 & 0 & 2 \\
\hline Phoca vitulina & 1 & 0 & 0 & 0 & 0 & 1 & 1 & 0 & 0 & 1 & 0 & 0 & 0 & 0 \\
\hline Erignathus barbatus & 1 & 0 & 1 & 0 & 0 & 1 & 1 & 1 & 1 & 1 & 0 & 1 & 0 & 0 \\
\hline Leptophoca lenis $†$ & 0 & 0 & 0 & 1 & 0 & 1 & 1 & 0 & 1 & 0 & 0 & 0 & 0 & 0 \\
\hline Pliophoca etrusca $\dagger$ & 2 & 0 & 0 & 1 & 1 & 1 & 1 & 0 & 0 & 0 & 0 & 1 & 0 & 1 \\
\hline Homiphoca capensis $\dagger$ & 2 & 0 & 0 & 1 & 1 & 1 & 0 & 1 & 0 & 0 & $?$ & 1 & 1 & 0 \\
\hline Phoca largha & 1 & 1 & 0 & 0 & 0 & 1 & 1 & 0 & 1 & 1 & 0 & 0 & 1 & 2 \\
\hline Pusa hispida & 2 & 1 & 0 & 0 & 0 & 1 & 0 & 1 & 1 & 1 & 0 & 0 & 1 & 0 \\
\hline Halichoerus grypus & 1 & 1 & 0 & 1 & 0 & 1 & 1 & 0 & 1 & 1 & 0 & 0 & 1 & 0 \\
\hline Pagophilus groenlandica & 1 & 0 & 0 & 0 & 0 & 1 & 0 & 0 & 1 & 1 & 0 & 0 & 0 & 0 \\
\hline Hadrokirus martini $\dagger$ & 1 & 1 & 1 & 1 & $?$ & 1 & 1 & 0 & 1 & 0 & 0 & 1 & 1 & 2 \\
\hline Planopusa semenovi $\dagger$ & 0 & 0 & 0 & 0 & 0 & 1 & 1 & 0 & 1 & 0 & 0 & 0 & 1 & 0 \\
\hline Pusa caspica & 0 & 0 & 0 & 0 & 0 & 1 & 1 & 0 & 1 & 0 & 0 & 0 & 1 & 0 \\
\hline Praepusa vindobonensis & 0 & 0 & 0 & 0 & 0 & 1 & 1 & 0 & 1 & 0 & 0 & 1 & 0 & 0 \\
\hline
\end{tabular}


resulting single Wagner most parsimonious tree generated by Winclada with 184 steps long, having Consistency Index of 0.75 , and Retention Index 0.81 .

The matrix of character-state data for 19 species of fossil and modern phocids is given in Table 3; in addition, the following taxa were used as outgroups: fossil representatives, such as Allodesmus and Puijila, and the recent mustelid Lontra.

\section{Skull}

1. Anterior palatine foramina: (0) round and deep; (1) oval and shallow; (2) indistinctively marked (Burns and Fay, 1970).

2. Palatal groove: (0) present; (1) absent.

3. Palatal process of maxillary bone: (0) flat; (1) convex.

4. Rostrum: (0) short, relative to skull; (1) elongated (Chapskii, 1974:299).

\section{Teeth}

5. Number of incisors: (0) 3/2; (1) 2/2; (2) 2/1 (Chapskii, 1974:289; in contrast to Burns and Fay 1970:380); (3) 3/1.

6. Roots of postcanine teeth (P2/p2 - P3/p3): (0) one (fused); (1) two (Berta and Wyss, 1994:51).

7. Roots of P4/p4: (0) three; (1) two; (2) one.

8. Crowns of postcanine teeth: (0) multicusped; (1) single-cusped.

9. Dimensions of postcanine teeth relative to longitudinal diameter of alveolus of upper canine: (0) more than $60.0 \%$; (1) less than $60.0 \%$ or sub-equal.

10. Basal cingulum of postcanine teeth: (0) well developed; (1) not developed.

11. Number of additional cusps of premolars: (0) more than two; (1) no additional cusps.

12. Premolar: (0) aligned parallel to axis of tooth-row; (1) seated obliquely.

13. Upper incisors: (0) arranged in a curved arcade; (1) arranged in a straight line.

14. Second and third upper incisors: (0) third larger than second; (1) second larger than third, (2) all upper incisors equal in size.

Nodes of the present tree (fig. 5) correspond to traditionally recognised phocid taxa. Only one new name is introduced here: inclusion of Devinophoca emryi within the subfamily Devinophocinae requires recognition of the new species.

The nodes on the cladogram shown in fig. 5 are supported by the following character transformations:

Node 1 (family Phocidae): 8(0). This paraphyletic group with an ancestral or primitive character (multicusped crowns of postcanine teeth) is treated as plesiomorphic for the family.

Node 2 (subfamily Devinophocinae, possibly paraphyletic): $1(0) ; 5(3) ; 7(0)$. The anterior palatal foramina are round and deep; number of incisors. Paraphyly of D. claytoni: three fused roots of the postcanine teeth.

Node 3 (subfamily Phocinae): $9(0,1) ; 5(0)$. The diameter of the infraorbital foramen is equal to or greater than the diameter of the maxillary canine alveolus; the length of auditory bulla is less than the distance between them. In addition, character 9(1) shows homoplasy in Neomonachus schauinslandi and Leptophoca lenis.

Node 4 (subfamily Monachinae): 2(1);3(1); 13(0,1). The relative dimensions of the frontal and maxillary parts of nasals; shape of the anterior palatine foramina; maxilla forms a long concavity; reduced number of incisors.

Node 5 (subfamily Cystophorinae): $5(2) ; 11(1) ; 14(1)$. The mastoid convexity directed sharply downward behind the mastoid process. Maxilla forms a short concavity; advance reduced number of incisors; no additional cusps on premolars. The second incisor is larger than the third one. 


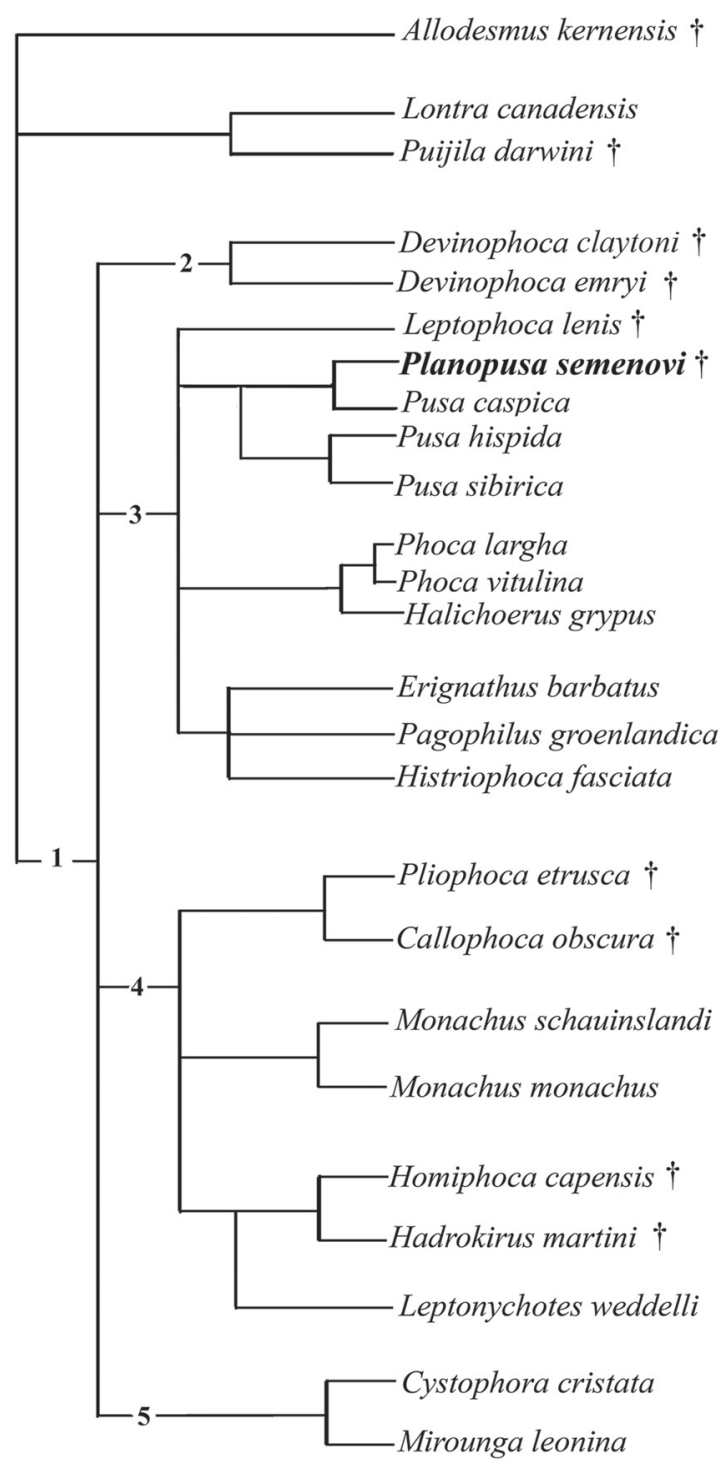

Fig. 5. The single, most parsimonious Wagner tree generated by Winclada with 184 steps long, having Consistency Index of 0.75 , and Retention Index 0.81 .

\section{Discussion and conclusions}

The new middle-late Miocene fossil material described herein supports previous views on dental morphology of seals (Koretsky and Rahmat, 2015). As was noted earlier, the rostral part of the Planopusa semenovi skull has three upper incisors (similar to seals of the subfamily Phocinae, primitive condition). Detailed descriptions of the dentition demonstrate that true seals ranging from 16 million years ago to the present have a generally uniform dental formula based on the total number of incisors: Phocinae (10 incisors; $3 / 2$ ); Cystophorinae (6 incisors; $2 / 1$ ); Monachinae (8 incisors $2 / 2$ ), and Devinophocinae (also 8 incisors as in Monachinae, but in a different combination: $3 / 1)$.

Although the new partial skull is incomplete, certain derived characters were clearly noticeable in Planopusa semenovi, including flattened palatal process of the maxilla, with short convexity; deep, oval-shaped anterior palatal foramen, connected to incisors via a deep, large palatal groove.

Phylogenetic analyses of fossil and recent Paratethyan Phocidae have been examined previously in several studies (Koretsky and Holec, 2002; Koretsky and Rahmat, 2013; 2015; Dewaele et al., 2017, 2018). Moreover, Pl. semenovi (consisting of a new description of the skull) is a closely related sister taxon to Pusa caspica based on morphology and phylogenetic analysis. Morphological character states and their polarity follow what was previously described by Koretsky and Rahmat (2015:43-44; tab. 4) and are used to create a matrix and phylogenetic tree. Some of the character states of this Pl. semenovi partial skull (tables 1-3) have the opposite polarity to that reported by Berta and Wyss (1994) and Burns and Fay (1970), while others have the same polarity as those recorded by Chapskii (1974). For a more detailed discussion of character polarities, see Koretsky and Grigorescu (2002). The polarity of a character is vital to determine what truly is the primitive or derived conditions in any specific taxon.

Based on stratigraphy of the Grytsiv locality, Paratethyan seals from the Middle-Late Miocene, specifically from the Sarmatian (Bessarabian stage of the Eastern Paratethys; MN 9; 11.146-11.056 Ma) occupied shallow marine waters with coral reef zones. Moreover, previous studies (Wolsan and Semenov, 1996; Nesin and Kowalski, 1997; Rzebik-Kowalska and Topachevsky, 1997; Morlo and Semenov, 2004; Rosina and Semenov, 2012; Semenov, 2001) examined terrestrial faunas, demonstrating that the variety of species from terrestrial to marine mammals found at the Grytsiv locality supports the hypothesis of numerous 
marine transgressions and regressions and changing sea level. The Middle Miocene had the warmest temperatures of the entire Miocene, displaying cyclical changes from humid/dry to warm/cooler conditions, and temperatures dropped and the climate became cooler and dryer by the beginning of the Late Miocene (Ivanov et al., 2011).

Previous researchers believed that primitive seals were large-sized animals (Wyss, 1994; Berta and Sumich, 1999). However, more recent studies (Finarelli and Flynn, 2008; Churchill et al., 2014 a, b; Koretsky et al., 2014; Dewaele et al., 2017, 2018) have demonstrated that early phocids were likely small-sized animals. Studies also determined that walruses and otariids have increased in body size over time, originating from smaller-sized ancestors (Churchill et al., 2014 a, b). This newly described Planopusa semenovi partial skull is an additional example of a small-sized seal, similar to the Miocene Praepusa, Batavipusa and Monachopsis and the modern Pusa. The finding of small-sized ancestral seals further suggests that modern seals have become larger over evolutionary history. In general, Planopusa semenovi is likely similar in size to the modern sea otter (based on the width of the rostrum) and clearly belongs to the subfamily Phocinae based on morphological assessment. Some scientists argued that only intact bones should be used for classification of seals (Dewaele et al., 2017, 2018). However, partial bones (both cranial and postcranial) give important information that cannot be disregarded. Any cranial information on fossil true seals is extremely important to resolve contentious phylogenetic relationships.

We would like to acknowledge Dr. D. Ivanoff (Department of Palaeontology, National Museum of Natural History, National Academy of Sciences of Ukraine, Kyiv) for his contributions towards this article.

\section{References}

Amson, E., Muizon, C. de. 2013. A new durophagous phocid (Mammalia: Carnivora from the late Neogene of Peru and considerations on monachine seals phylogeny. Journal of Systematic Palaeontology. Doi: 10.1080/14772019.2013.799610.

Berta, A. and Wyss, A. R. 1994. Pinniped phylogeny. Proceedings of the San Diego Society of Natural History. 29, 33-36.

Berta, A., Sumich, J. L. 1999. Marine Mammals: Evolutionary Biology. Academic Press, San Diego, 1-560.

Burns, J. and Fay, S. 1970. Comparative morphology of the skull of the Ribbon seal, Histriophoca fasciata, with remarks on systematics of Phocidae. Journal of zoology, 161 (3), 363-394.

Chapskii, K. K. 1974. In defense of classical taxonomy of the seals of the family Phocidae. Trudy Zoological Institute Academy of Sciences USSR. 53, 282-334 [In Russian].

Churchill, M., Clementz, M. T., Kohno, N. 2014 a. Predictive equations for the estimation of body size inseals and sea lions (Carnivora: Pinnipedia). Journal of Anatomy, 225 (2), 232-245.

Churchill, M., Clementz, M. T., Kohno, N. 2014 b. Cope's rule and the evolution of body size in Pinnipedimorpha (Mammalia: Carnivora). Evolution, 69, 201-215.

Dewaele, L., Amson, E., Lambert, O., and Louwye, S. 2017. Reappraisal of the extinct seal "Phoca" vitulinoides from the Neogene of the North Sea Basin, with bearing on its geological age, phylogenetic affinities, and locomotion. PeerJ, 5, e3316.

Dewaele, L., Lambert, O., and Louwye, S. 2018. A critical revision of the fossil record, stratigraphy and diversity of the Neogene seal genus Monotherium(Carnivora, Phocidae). Royal Society open science, 5 (5), 171669. doi: $10.1098 /$ rsos. 171669

Finarelli, J. A., Flynn, J. J. 2008. Ancestral State Reconstruction of Body Size in the Caniformia (Carnivora, Mammalia): The Effects of Incorporating Data from the FossiL Record. Systematic Biology, 55 (2), 301-313.

Goloboff, P. 1999. NONA ver. 2 Published by theauthor, Tucumán, Argentina.

Ivanov, D., Utescher,T., Mosbrugger,V., Syabryaj, S., Djordjević-Milutinović, D., and Molchanoff, S. 2011. Miocene vegetation and climate dynamics in Eastern and Central Paratethys (Southeastern Europe). Palaeogeography, Palaeoclimatology, Palaeoecology, 304 (3-4), 262-275.

Kirscher, U., Prieto, J., Bachtadse, V., Abdul Aziz, H., Doppler, G., Hagmaier, M., Böhme, M. 2016. A biochronologic tie-point for the base of the Tortonian stage in European terrestrial settings: magnetostratigraphy of the topmost upper freshwater molasse sediments of the North Alpine Foreland Basin in Bavaria (Germany). Newsl. Stratigr., 49 (3), 445-467.

Koretsky, I. A., Ray, C. 1994. Cryptophoca, new genus for Phoca maeotica (Pinnipedia, Phocinae) from Upper Miocene deposits in the Northern Black Sea region. Proceedings of the Biological Society of Washington, 107 (1),17-26.

Koretsky, I. A. 2001. Morphology and Systematics of Miocene Phocinae (Mammalia: Carnivora) from Paratethys and the North Atlantic Region. Geologica Hungarica, Series Paleontologica, Budapest, Fasciculus, 54, 1-109. 
Koretsky, I. A.. Holec, P. 2002. A primitive seal (Mammalia: Phocidae) from the Early Middle Miocene of Central Paratethys. Smithsonian Contribution to Paleobiology, 93, 163-178.

Koretsky, I. A., Grigorescu, D. 2002. The fossil monk seal Pontophoca sarmatica (Alekseev) (Mammalia: Phocidae: Monachinae) from the Miocene of eastern Europe. Smith. Contrib. Paleobiology, 93, 149-162. Koretsky I. A. 2003. New Finds of Sarmatian Seals (Mammalia: Carnivora: Phocinae) from Southern Hungary. In: Petculescu, A. and Ştiucă, E., eds. Advances in Vertebrate Paleontology, A tribute to Constantin Radulescu and Petre Samson, Bucharest, 63-70.

Koretsky, I. A., Rahmat, S. J. 2013. First Record of fossil Cystophorinae (Carnivora, Phocidae): Middle Miocene seals from the Northern Paratethys. Rivista Italiana di Paleontologia e Stratigrafia, 119 (3), 325-350.

Koretsky, I. A., Rahmat, S. J. 2015. A New Species of the Subfamily Devinophocinae (Carnivora: Phocidae) from the Central Paratethys. Rivista Italiana di Paleontologia e Stratigrafia, 121 (1),1-17.

Korotkevich, E. L. 1988. A history of formation of hipparion fauna of Eastern Europe. Naukova Dumka, Kiev, 1-164 [In Russian].

Morlo, M., Semenov, Y. 2004. New Carnivora (Mammalia) from the Early Vallesian (Late Miocene, MN9) of Ukraine. Journal of Vertebrate Paleontology, 24 (3), Supplement, 96A.

Nesin, V., Kovalchuk, O. 2020. A new late Miocene Anomalomys species from western Ukraine with implications for the diversity and evolution of anomalomyid rodents in Eastern Europe. Historical Biology. Doi: $10.1080 / 08912963.2020 .1742711$

Nesin, V. A., Kowalski, K. 1997. Miocene Gliridae (Mammalia, Rodentia) from Grytsiv (Ukraine). Acta Zoologica Cracoviensia, 40 (2), 209-222.

Nesin, V. A., Nadachowski, A. 2001. Late Miocene and Pliocene small mammal faunas (Insectivora, Lagomorpha, Rodentia) of Southeastern Europe. Acta Zoologica Cracoviensia, 44 (2),107-135.

Nixon, K. C. 1999. WinClada ver. 1.0000 Published bythe author, Ithaca, NY, USA.

Rahmat, S. J., Koretsky, I. A. 2016. First Record of Postcranial Bones in Devinophoca emryi (Carnivora, Phocidae, Devinophocinae). Vestnik Zoologii, 50 (1), 71-86.

Rahmat, S., Koper, 1., Crowell, M., Alexander, A., Koretsky, I. A. 2017. Society for Vertebrate Paleontology presentation.

Rahmat, S. J., Koretsky, I. A. 2018. Mandibular morphology of the mid-Miocene seal Devinophoca claytoni (Carnivora, Phocidae, Devinophocinae). Vestnik Zoologii, 52 (6), 509-520. Doi: 10.2478/vzoo-2018-0052.

Ray, C. E., Bohaska, D. J., Koretsky I. A., Ward, L. W., Barnes, L. G. 2008. Geology and Paleontology of the Lee Creek Mine, North Carolina, IV. Virginia Museum of Natural History Special Publication, 14, 81-140.

Rosina, V. V., Semenov, Y. A. 2012. New taxa of vespertilionid bats (Chiroptera, Mammalia) from late Miocene of Ukraine. Neues Jarhrbuch für Geologie und Paläontologie-Abhandlungen, 264 (3), 191-203.

Rzebik-Kowalska, B., Topachevsky, V. O. 1997. Insectivora (Mammalia) form the Miocene of Grytsiv in Ukraine. I. Heterosoricida Viret and Zapfe, 1951. Acta Zoologica Cracoviensia, 40 (2), 237-247.

Semenov, Y. 2001. Stratigraphic distribution of the terrestrial carnivores in the Vallesian and Turolian of Ukraine. Beiträge zur Paläontologie, 26, 139-144.

Topachevsky, V. A., Nesin, V. A., Topachevsky, I. V. 1998. Biozonal microtheriological scheme (stratigraphic distribution of small mammals -Insectivora, Lagomorpha, Rodentia) of the Neogene of the northern part of the East Paratethys. Vestnik Zoologii, 32, 76-87 [In Russian].

Topachevsky, V. A., Skorik, A. F. 1992. The Neogene and Pleistocene lower cricetids of Southern Europe. Naukova Dumka, Kiev, 1-242 [In Russian].

Topachevsky, V. A., Nesin, V. A., Topachevsky, I. V. and Semenov, Y. A. 1996. The oldest Middle Sarmatian small mammals fauna locality (Insectivora, Lagomorpha, Rodentia) in Eastern Europe. Dopovidi Nationalnoi Akademii Nauk Ukraini, 2, 107-110.

Vangengeim, E. A., Lungu A. N., Tesakov, A. S. 2006. Age of the Vallesian Lower Boundary (Continental Miocene of Europe). Stratigraphy and Geological Correlation, 14 (6), 655-667.

Vasilyan, D., Böhme, M., Chkhikvadze, V. M., Semenov, Y., Joyce, W. G. 2013. A new giant salamander (Urodela, Pancryptobrancha) from the Miocene of Eastern Europe (Grytsiv, Ukraine). J. Vert. Paleontol., 33 (2), 301-318.

Wolsan, M., Semenov, Y. A. 1996. A revision of the late Miocene mustelid carnivoran Eomellivora. Acta Zoologica Cracoviensia, 39 (1), 593-604.

Wozencraft, C. 1989. The phylogeny of the Recent Carnivora. In: Gittleman, J. L., ed. Carnivore Behavior, Ecology, and Evolution, New York, 495-535.

Wyss, A. R., Flynn, J. J. 1993. A phylogenetic analysis and definition of the Carnivora. In: Szalay, F. S., Novacek, M. J., McKenna, M. C., eds. Mammal Phylogeny: Placentals. Springer-Verlag, New York, 32-53.

Wyss A.R. 1994. The evolution of body size in phocids: some ontogenetic and phylogenetic observations. In: Berta, A., Deméré, T. A., eds. Contributions in Marine Mammal Paleontology Honoring Frank C. Whitmore, Jr. Proceedings of the San Diego Society of Natural History, 29, 69-77. 